\title{
Procedural Misjoinder: The Quest for a Uniform Standard*
}

\section{INTRODUCTION}

Litigants know the importance of the litigation forum. ${ }^{1}$ Recognizing favorable judges and evidentiary rules, ${ }^{2}$ plaintiffs generally want to litigate in state court while defendants prefer federal court. ${ }^{3}$ The potential for an unfavorable forum, as well as the unfavorable rulings that might result, set up a fierce forum selection battle among litigants. ${ }^{4}$ Procedural misjoinder, ${ }^{5}$ a doctrine that allows the federal court to take jurisdiction when joinder rules have been used improperly, has become an important tool in the battle for a favorable forum. ${ }^{6}$ However, the lack of a consistent framework for the doctrine has left courts and litigants with a great deal of uncertainty. ${ }^{7}$

* Jason Harmon. J.D. Candidate 2015, University of Kansas School of Law; B.S. 2012, Utah Valley University. I would like to thank my wife, McKell, and my children for inspiring me to be my best self, both personally and professionally. I would also like to thank Professor Ellen Sward, Professor Laura Hines and the Kansas Law Review's Miriam Friesen for their invaluable feedback while writing this comment.

1. See Note, Forum Shopping Reconsidered, 103 HARV. L. REV. 1677, 1677 (1990).

2. E. Farish Percy, Making a Federal Case of it: Removing Civil Cases to Federal Court Based on Fraudulent Joinder, 91 IowA L. REv. 189, 206 \& n.110 (2005) (describing a "variety of factors that may influence plaintiffs' general preference to litigate in state court," including local attorneys' comfort with home-state court systems, the increased chances of summary judgment in federal courts, the cost of federal pretrial activities, and the relative liberality of state rules governing permissive joinder).

3. Id.

4. See E. Farish Percy, Defining the Contours of the Emerging Fraudulent Misjoinder Doctrine, 29 HARV. J.L. \& PUB. POL'Y 569, 570-71 (2006) (“[P]laintiffs, who generally prefer to litigate in state court, and defendants, who generally prefer to litigate in federal court, continue to fight forum selection battles with increasing intensity ...." (citation omitted)).

5. Procedural misjoinder is sometimes referred to as fraudulent misjoinder, but is actually a distinct concept. Fraudulent joinder occurs when the parties have no factual or legal basis for joining the claims. Laura J. Hines \& Steven S. Gensler, Driving Misjoinder: The Improper Party Problem in Removal Jurisdiction, 57 Ala. L. Rev. 779, 781 (2006). Procedural misjoinder, on the other hand, occurs when the party has no procedural basis for joining the claims. Percy, supra note 4 , at 782 .

6. See Hines \& Gensler, supra note 5, at 783 (describing procedural misjoinder as a vital judicial tool to police joinder gamesmanship).

7. See, e.g., Rutherford v. Merck \& Co. Inc., 428 F. Supp. 2d 842, 852-53 (S.D. Ill. 2006); Reuter v. Medronics, Inc., No. 10-3019 (WJM), 2010 WL 4628439, at *4 (D.N.J. Nov. 5, 2010); 
The plaintiff, as the "master of the complaint" initially chooses the forum of the litigation. ${ }^{8}$ The defendant, however, has a statutory right to remove a case involving state law to federal court based on diversity of citizenship. ${ }^{9}$ Removal based on diversity jurisdiction is proper when the amount in controversy is more than $\$ 75,000$ and there is complete diversity among the parties. ${ }^{10}$ Parties are completely diverse if no plaintiffs and no defendants are citizens of the same state. ${ }^{11}$

Procedural misjoinder addresses the complete diversity requirement. $^{12}$ Anticipating removal by defendants, plaintiffs join at least one plaintiff from each state in which the defendants are citizens. ${ }^{13}$ This anticipatory action has been termed a "jurisdictional spoiler." 14 After defendants remove the case to federal court, the plaintiffs move to remand to state court by citing of the lack of complete diversity. ${ }^{15}$ In response, the defendants urge the court to apply the procedural misjoinder doctrine and ignore the citizenship of the parties improperly joined to destroy diversity. ${ }^{16}$ Procedural misjoinder allows the court to disregard the citizenship of the "jurisdictional spoilers" and exercise removal jurisdiction. ${ }^{17}$ Under the procedural misjoinder doctrine, the

Palmer v. Davol, Inc., No. 07-md-1842-ML, No. 08-cv-02499-ML, 2008 WL 5377991, at*3 (D.R.I. Dec. 23, 2008); Asher v. Minnesota Mining \& Mfg. Co., No. Civ. A. 04CV522KKC, 2005 WL 1593941, at *5 (E.D. Ky. June 30, 2005).

8. Caterpillar Inc. v. Williams, 482 U.S. 386, 392 (1987).

9. 28 U.S.C. $§ 1441$ (b) (2012).

10. 28 U.S.C. $\$ 1332$ (a) (2012).

11. 28 U.S.C. $\$ 1332(2012)$.

12. Hines \& Gensler, supra note 5 , at 780 .

13. See Hines \& Gensler, supra note 5, at 781 ("It is no secret that plaintiffs often deliberately structure their state court lawsuits to prevent removal by defendants to federal court."); 1 MiCHAEL L. WiLliams \& BRIAN S. CAMPF, LitigATING TORT CASES § 5:33 ("In recent tabacco litigation, there has been an effort to add retailers and local employees of cigarette manufacturers to keep cases in state court.").

14. Hines \& Gensler, supra note 5, at 781; Percy, supra note 4, at 571.

15. See, e.g., In re Rezulin Prods. Liab. Litig., 168 F. Supp. 2d 136, 147 (S.D.N.Y. 2001) (acknowledging that several courts have applied procedural misjoinder in the context of remand petitions).

16. See, e.g., In re Propecia (Finasteride) Prod. Liab. Litig., No. 12-MD-2331(JG)(VVP), 2013 WL 3729570, at*1 (E.D.N.Y. May 17, 2013) ("[The defendants] also argue that the misjoinder of the plaintiffs is egregious and therefore the claims should be severed and the motion to remand denied.").

17. See Tapscott v. MS Dealer Serv. Corp., 77 F.3d 1353, 1360 (11th Cir. 1996), abrogated on other grounds by Cohen v. Office Depot, Inc., 204 F.3d 1069, 1072 (11th Cir. 2000) (holding that the diversity of citizenship was satisfied by reason of fraudulent joinder). Though the Tapscott court referred to the procedural misjoinder as a species of fraudulent joinder, courts and commentators agree that procedural misjoinder is a distinct doctrine. See, e.g., Hines \& Gensler, supra note 5, at 781; Percy, supra note 4, at 782; Reeves v. Pfizer, Inc., 880 F. Supp. 2d 926, 927 (S.D. Ill. 2012). 
court can take jurisdiction over the diverse parties and remand only the non-diverse parties to state court. ${ }^{18}$ Recognizing the need to preserve the defendants' statutory right of removal, many federal courts have adopted the procedural misjoinder doctrine. ${ }^{19}$

Multi-plaintiff pharmaceutical actions present an illustrative and common example of the policy concerns addressed by the doctrine. ${ }^{20}$ In an action against a large pharmaceutical company potential plaintiffs span the continent and possibly the globe. Thus, in a pharmaceutical action a plaintiff can likely find another person who is a citizen of the same state and who has a potential claim against the company. The plaintiff, then, need only join that person to the lawsuit to defeat complete diversity even if the joinder of that person constitutes misjoinder under Rule 20. Absent the procedural misjoinder doctrine, the plaintiff would successfully prevent the defendant from removing to federal court by manipulating the joinder rules. ${ }^{21}$

On the other hand, federal courts are courts of limited jurisdiction and should not use judicial mechanisms to infringe on the jurisdiction of the state courts. ${ }^{22}$ Plaintiffs who have similar claims against the same or a similar pharmaceutical company may have good reason to join the suits together in state court. Indeed, questions of law or fact may be common and expensive to litigate. ${ }^{23}$ An unclear standard could result in federal

18. See, e.g., In re Diet Drugs Prods. Liab. Litig., No. Civ. A. 98-20478, 1203, 1999 WL 554584, at *4 (E.D. Pa. July 16, 1999) ("Because the court finds that the Plaintiffs that destroy diversity jurisdiction are fraudulently joined it may ignore the citizenship of the [sic] those parties and exercise jurisdiction over this civil action.").

19. See, e.g., Rezulin, 168 F. Supp. 2d at 147 (explaining that while cost and efficiency benefits of joining plaintiffs are not immaterial, "they simply do not carry the same weight when balanced against the defendant's right to removal"); In re Diet Drugs (Phentermine, Fenfluramine, Dexfenfluramine) Prods. Liab. Litig., 294 F. Supp. 2d 667, 673 (E.D. Pa. 2003) (explaining that a non-diverse plaintiff cannot defeat a defendant's right to removal "if there is no reasonable basis for the joinder of that non-diverse plaintiff" because "[s]uch 'procedural misjoinder' would be a plaintiff's purposeful attempt to defeat removal" (citation omitted)).

20. Propecia, 2013 WL 3729570 , at *6-8.

21. 13F Charles Alan Wright et al., Federal Practice and Procedure $\S 3641.1$ (3d ed.) ("It probably is the case that the most common device used to destroy diversity of citizenship jurisdiction and the possibility of removal is for a state court plaintiff to join a party whose presence in the case creates the prohibited cocitizenship on both sides of the litigation, thereby preventing satisfaction of the complete diversity rule.")

22. See Moore v. Mobil Oil Corp., 904 F. Supp. 587, 588 (E.D. Tex. 1995) (“This court cannot rewrite the removal statute to grant itself subject matter jurisdiction."); Rutherford v. Merck \& Co. Inc., 428 F. Supp. 2d 842, 852 (S.D. Ill. 2006) ("In the Court's view, [procedural misjoinder] is an improper expansion of the scope of federal diversity jurisdiction by the federal courts." (citing In re Norplant Contraceptive Prod. Liab. Litig., 976 F. Supp. 559, 561 (E.D. Tex. 1997))).

23. See Rezulin, 168 F. Supp. 2d at 147 (acknowledging the costs and efficiency benefits of joining plaintiffs). 
courts inappropriately expanding their diversity jurisdiction without the authorization of Congress. ${ }^{24}$ Therefore, a clear and uniform standard is essential to clearly define the boundaries of the doctrine. ${ }^{25}$

Although courts have often applied the procedural misjoinder to this common scenario, the development of the doctrine has been erratic and confusing. The questions surrounding the doctrine have been primarily focused on two questions: 1 ) whether to adopt procedural misjoinder; ${ }^{26}$ and 2) what type of misjoinder warrants application of the doctrine. ${ }^{27}$ This comment, while briefly describing the benefits of adopting procedural misjoinder, explores the second question: what type of misjoinder warrants application of the doctrine. ${ }^{28}$

Part II of this comment describes the development of the procedural misjoinder doctrine from its adoption in Tapscott v. MS Dealer Service Corporation $^{29}$ and describes the difficulty that followed. This section specifically focuses on two of the circuit courts that have addressed the issue: the Eleventh Circuit in Tapscott and the Eighth Circuit in In re Prempro Products Liability Litigation. ${ }^{30}$ Part III briefly discusses the benefits of adopting the doctrine and analyzes the shortcomings of Prempro, noting that the time for clarification is now.

Finally, this comment argues that although the evolution and application of the procedural misjoinder doctrine has been inconsistent, a framework for application has begun to emerge. Accordingly, courts applying the procedural misjoinder doctrine should adopt a multi-factor

\footnotetext{
24. Percy, supra note 4 , at 621 .

25. Id.

26. See, e.g., Hines \& Gensler, supra note 5 (arguing that the procedural misjoinder doctrine should be adopted); Ronald A. Parsons, Jr., Should the Eighth Circuit Recognize Procedural Misjoinder?, 53 S.D. L. REV. 52 (2008) (urging the Eighth Circuit to reject the doctrine); see also Rutherford, 428 F. Supp. 2d at 852 (refusing to adopt the doctrine); Fore Invs., LLC v. Travelers Indem. Co., No. 1:12-CV-01702-SEB-DML, 2013 WL 3467328, at*4-*5 (S.D. Ind. July 9, 2013) (noting that district courts are divided on the viability of the procedural misjoinder doctrine).

27. See, e.g., Percy, supra note 4 (arguing that the corresponding fraudulent joinder standard is the appropriate standard to apply); Rezulin, 168 F. Supp. 2d at 147-48 (refusing to apply the egregiousness standard).

28. In addition, there has been some question as to which procedural rules apply, state or federal. See, e.g., Palermo v. Letourneau Techs. Inc., 542 F. Supp. 2d 499, 516 (S.D. Miss. 2008) ("The first determination to be made is whether, when considering the joinder of parties, a court should rely on Rule 20 of the Federal Rules of Civil Procedure or its state law counterpart . ..."). Oftentimes, however, the state and federal rules are nearly identical, making the question more theoretical than practical. Conk v. Richards \& O’Neil, LLP, 77 F. Supp. 2d 956, 971 (S.D. Ind. 1999).

29. 77 F.3d 1353, 1360 (11th Cir. 1996), abrogated on other grounds by Cohen v. Office Depot, Inc., 204 F.3d 1069, 1072 (11th Cir. 2000).

30. 591 F.3d 613 (8th Cir. 2010).
} 
test for uniform application.

\section{BACKGROUND}

\section{A. Procedural Misjoinder: An Introduction}

Procedural misjoinder, often referred to as fraudulent misjoinder, ${ }^{31}$ is a doctrine that protects a party from losing their right to remove a case to federal court because of misuse of the joinder rules. ${ }^{32}$ A party can remove a case to federal court if it could have been filed there in the first place, ${ }^{33}$ and under 28 U.S.C $\S 1332$ the federal court has jurisdiction over cases when the parties are completely diverse and the amount in controversy is over $\$ 75,000 .^{34}$ Procedural misjoinder addresses the first prong the federal court's Section 1332 jurisdiction-complete diversity.

Although the Constitution allows a federal court to take jurisdiction over cases where there is minimal diversity, ${ }^{35}$ Congress, through statute only allows federal courts to have jurisdiction when the parties are completely diverse. ${ }^{36}$ Minimal diversity requires only that one party be a citizen of a different state than at least one opposing party. ${ }^{37}$ Complete diversity, on the other hand, is present when no plaintiffs and no defendants are citizens of the same state. ${ }^{38}$ Accordingly, when one defendant is from the same state as one plaintiff, complete diversity does not exist and the federal court cannot have jurisdiction over the case.

Procedural misjoinder addresses the situation where complete diversity exists technically, but perhaps not rightfully. Rule 20 of the Federal Rules of Civil Procedure allows parties to be joined if they assert relief "arising out of the same transaction, occurrence, or series of transactions or occurrences" and any question of law or fact common to the plaintiffs will arise in the action. ${ }^{39}$ Typically, courts have applied Rule 20 liberally to promote judicial efficiency. ${ }^{40}$ However, misjoinder

31. See supra note 5 and accompanying text.

32. See supra note 19 and accompanying text.

33. 28 U.S.C. $\$ 1441$ (b) (2012).

34. 28 U.S.C. $\$ 1332$ (2012).

35. State Farm Fire \& Cas. Co. v. Tashire, 386 U.S. 523, 530-31 (1967).

36. 28 U.S.C. $\$ 1332$ (2012).

37. State Farm, 386 U.S. at 530.

38. Id.

39. FED. R. CIV. P. 20.

40. 14B Charles Alan Wright et Al., Federal Practice and Procedure $§ 1653$ (4th ed.); see also Mosley v. Gen. Motors Corp., 497 F.2d 1330, 1334 (8th Cir. 1974). 
occurs when the parties are joined despite not meeting the requirements of Rule $20 .^{41}$

Parties have often attempted to use misjoinder as a tool to defeat jurisdictional restrictions, ${ }^{42}$ and historically the doctrine of fraudulent joinder has addressed this problem. ${ }^{43}$ Fraudulent joinder happens when the parties have no factual or legal basis for joining the claims. ${ }^{44}$ Fraudulent joinder doctrine allows the court to ignore the lack of diversity and take jurisdiction over the case.

Procedural misjoinder was first described as a species of fraudulent joinder. $^{45}$ However, courts and commentators agree that procedural misjoinder is a distinct and separate doctrine. ${ }^{46}$ Procedural misjoinder occurs when the party has no procedural basis for joining the claims. ${ }^{47}$ In other words, a plaintiff that is joined may have a claim against one of the defendants, but it does not arise out of the same transaction or occurrence as the other plaintiffs. Put simply, procedural misjoinder occurs when there is no reason to join the claims, and fraudulent joinder occurs when there is no claim. ${ }^{48}$ Procedural misjoinder, assuming the jurisdiction accepts the doctrine as viable, allows the federal court to take jurisdiction over the diverse claims. ${ }^{49}$

41. Tapscott v. MS Dealer Serv. Corp., 77 F.3d 1353, 1360 (11th Cir. 1996), abrogated on other grounds by Cohen v. Office Depot, Inc., 204 F.3d 1069, 1072 (11th Cir. 2000); WRIGHT, supra note $40, \S 3723$.

42. See Hines \& Gensler, supra note 5, at 781 ("It is no secret that plaintiffs often deliberately structure their state court lawsuits to prevent removal by defendants to federal court.").

43. See Tapscott, 77 F.3d at 1360 (holding that the diversity of citizenship requirement was satisfied by reason of fraudulent joinder); see also Paul Rosenthal, Improper Joinder: Confronting Plaintiffs' Attempts to Destroy Federal Subject Matter Jurisdiction, 59 AM. U. L. REv. 49, 60-65 (2008) (discussing plaintiffs' strategies to avoid removal and defendants' common response: fraudulent joinder); WRIGHT, supra note 21, $\S 3641.1$ (explaining that an improper joinder of a nondiverse party "typically is followed by a motion to remand by the plaintiff, which will be opposed by the removing defendant with the assertion that the state court joinder was 'fraudulent."'); Percy, supra note 2, at 206 (noting that the Supreme Court has long recognized the doctrine of fraudulent joinder).

44. See, e.g., Chesapeake \& Ohio Ry. Co. v. Cockrell, 232 U.S. 146, 152 (1914) (holding that a defendant's right to removal cannot be defeated by a joinder of a party with "no real connection to the controversy").

45. See supra note 5 and accompanying text.

46. See supra note 5 and accompanying text.

47. Hines \& Gensler, supra note 5, at 780 .

48. Tomlinson v. Deutsche Bank Nat'l Trust Co., No. CV 13-00554 SOM-BMK, 2014 WL 346922, at *7 (D. Haw. 2014).

49. See, e.g., In re Diet Drugs, No. Civ. A. 98-20478, 1203, 1999 WL 554584, at *4 (E.D. Pa. July 16, 1999) ("Because the court finds that the Plaintiffs that destroy diversity jurisdiction are fraudulently joined it may ignore the citizenship of the [sic] those parties and exercise jurisdiction over this civil action."). 
Procedural misjoinder is often applied in cases with similar procedural posture. ${ }^{50}$ The plaintiff is the "master of the complaint" and initially chooses the forum for the litigation. ${ }^{51}$ Recognizing the importance of the litigation forum, plaintiffs generally prefer to litigate in state court because, in general, they see state court judges and evidentiary rules as favorable to their position. ${ }^{52}$ So, many of the cases that ultimately apply procedural misjoinder begin in state courts.

Defendants often prefer the federal courts to state courts, ${ }^{53}$ and 28 U.S.C. $\S 1441$ gives a defendant the right to remove a case to federal court if it could have been brought in federal court in the first place. ${ }^{54}$ Anticipating that the defendant will remove the case to federal court if the parties are diverse, plaintiffs join parties to suit that are non-diverse. In other words, the plaintiffs join at least one additional plaintiff that is a citizen of the same state as at least one defendant. Thus, at least technically, complete diversity does not exist and defendants cannot remove the case to federal court. Enter procedural misjoinder.

Defendants remove the case to federal court asserting that the plaintiffs have been misjoined, and that, applying the procedural misjoinder doctrine, the federal court has jurisdiction over the diverse claims. Plaintiffs argue that complete diversity is lacking and the case should be remanded to state court. Hence, procedural misjoinder is often applied when the court addresses the plaintiffs' motion to remand to state court.

\section{B. Development of Procedural Misjoinder}

1. A New Doctrine: Tapscott v. MS Dealer Serv. Corp. ${ }^{55}$

The Eleventh Circuit first adopted the procedural misjoinder doctrine

50. See In re Rezulin Prods. Liab. Litig., 168 F. Supp. 2d 136, 147 (S.D.N.Y. 2001) (acknowledging that several courts have applied procedural misjoinder in the context of remand petitions); WRIGHT, supra note $21, \S 3641.1$ ("If the defendant believes the state court joinder of a nondiverse party to be improper, he or she will remove the action. That typically is followed by a motion to remand by the plaintiff, which will be opposed by the removing defendant with the assertion that the state court joinder was 'fraudulent."').

51. Caterpillar Inc. v. Williams, 482 U.S. 386, 392 (1987).

52. See supra note 4.

53. $I d$.

54. 28 U.S.C. $\S 1441$ (b) (2012).

55. 77 F.3d 1353, 1360 (11th Cir. 1996), abrogated on other grounds by Cohen v. Office Depot, Inc., 204 F.3d 1069, 1072 (11th Cir. 2000). 
in Tapscott v. MS Dealer Service Corporation. ${ }^{56}$ In that case, the plaintiffs tried to merge two distinct lawsuits. ${ }^{57}$ In the initial and first amended complaint, a group of plaintiffs sued a group of defendants for fraud arising from the sale of automobile service contracts. ${ }^{58}$ The plaintiffs and defendants were not completely diverse, that is, some plaintiffs and some defendants were citizens of Alabama. ${ }^{59}$

The second amended complaint added another group of plaintiffs and defendants. ${ }^{60}$ This group of plaintiffs sued for fraud arising from the sale of extended service contracts of retail products. ${ }^{61}$ Plaintiffs then dismissed several of the defendants from the second group, leaving only one defendant. ${ }^{62}$ The remaining defendant, Lowe's Home Center, was a citizen of North Carolina. ${ }^{63}$ No plaintiff in the second group was a citizen of North Carolina; thus, the second group was completely diverse. $^{64}$

The plaintiffs who were added in the second amended complaint brought an entirely distinct claim. And by joining those claims into the same lawsuit, plaintiffs attempted to keep a diverse defendant in state court. ${ }^{65}$ The defendant, Lowe's Home Center, removed the case to federal court and moved to sever the non-diverse claims. ${ }^{66}$ The plaintiffs then moved to remand to state court. ${ }^{67}$ The district court granted Lowes' Motion to Sever and remanded the non-diverse actions to state court. The court, however, declined to remand the action against Lowe's. ${ }^{68}$

On appeal, the Eleventh Circuit upheld the district court's decision. The court noted that the non-diverse defendants had "no real connection with the controversy" involving the second group of plaintiffs and Lowe's. $^{69}$ Moreover, the court recognized that the plaintiffs had attempted to use joinder to defeat diversity jurisdiction and determined

\footnotetext{
56. Id. at 1360 .

57. Id.

58. Id. at 1355.

59. $I d$

60. Id.

61. Id.

62. Id.

63. Id.

64. Id.

65. Id. at 1360 .

66. Id. at 1355 .

67. $I d$.

68. Id. at 1360 .

69. Id.
} 
that this misjoinder-what this article refers to as procedural misjoinder - constituted a new species of fraudulent joinder. ${ }^{70}$

The court then pointed out that procedural misjoinder should only be applied when the misjoinder is "egregious."71 Tapscott did not define what egregious means, ${ }^{72}$ and the failure to articulate a test for egregiousness has created great difficulties for district courts attempting to apply the procedural misjoinder doctrine.

\section{Applying the New Doctrine}

Following Tapscott, district courts struggled to apply the doctrine and some outside the Eleventh Circuit dismissed it altogether. ${ }^{73}$ The facts in Tapscott were unusual when compared to its common application. $^{74}$ Tapscott established, however, that at some point misjoinder cannot be used as a tool to defeat diversity jurisdiction. As a result, district courts were left knowing two things: the misjoinder in Tapscott was egregious and when a misjoinder is egregious parties cannot use it to defeat removal. Consequently, district courts attempting to define egregious did so inconsistently. ${ }^{75}$

For example in In re Diet Drugs, ${ }^{76}$ a district court in Alabama attempted to define the meaning of egregious by focusing on the plaintiffs' motive for joining the parties. The complaint in that case was originally filed in Alabama state court. ${ }^{77}$ Two of the nine plaintiffs were citizens of Alabama. ${ }^{78}$ The court concluded the joinder of the nonresident plaintiffs was egregious for four reasons. First, only two of nine plaintiffs were citizens of Alabama. ${ }^{79}$ Second, none of the non-resident plaintiffs had any contact with Alabama. ${ }^{80}$ Third, none of the nonresident plaintiffs alleged any reasons for filing in Alabama. ${ }^{81}$ And

\footnotetext{
70. Id.

71. Id.

72. Percy, supra note 4, at 609.

73. E.g., Rutherford v. Merck \& Co., 428 F. Supp. 2d 842, 855 (S.D. Ill. 2006).

74. Infra section III.B.1.

75. Compare In re Diet Drugs, No. Civ. A. 98-20478, 1203, 1999 WL 554584, at *4 (E.D. Pa. July 16, 1999), with Rutherford, 428 F. Supp. 2 d at 855.

76. No. Civ. A. 98-20478, 1203, 1999 WL 554584 (E.D. Pa. 1999).

77. Id. at $* 1$.

78. Id. at $* 3$.

79. $I d$.

80. $I d$.

81. Id.
} 
finally, the court noted that because the non-resident plaintiffs were citizens of the same states as at least one defendant, ${ }^{82}$ they had no reason for filing in Alabama except to defeat removal by the defendants. Thus, the court concluded that the misjoinder was egregious because the plaintiffs' sole purpose was to defeat diversity jurisdiction. ${ }^{83}$

In Greene v. Wyeth, ${ }^{84}$ on the other hand, a Nevada district court expressly refused to rely upon the plaintiffs' motive for joinder in applying the procedural misjoinder doctrine. ${ }^{85}$ The court noted that the plaintiffs were entitled to avoid diversity jurisdiction and to draft their complaint accordingly. ${ }^{86}$ But, the court explained, the misjoinder was egregious because it "clearly accomplish[ed] no other objective than the manipulation of the forum., 87

Taking yet another approach in In re Rezulin Products Liability Litigation, ${ }^{88}$ a New York district court specifically rejected the requirement that the misjoinder be egregious at all. ${ }^{89}$ In this multiplaintiff pharmaceutical action, the court acknowledged that the plaintiffs' claims had "at least an empirical, if not a transactional, relationship." 90 Still, the court found the application of procedural misjoinder appropriate. These cases illustrate the inconsistent attempt to define the type of misjoinder that warrants application of procedural misjoinder.

Indeed, the court in Rutherford $v$. Merck \& Co. ${ }^{91}$ surveyed the case law addressing procedural misjoinder and highlighted its inconsistent application. ${ }^{92}$ As the court described, the ten years since the Tapscott ruling had resulted in "enormous judicial confusion." 93 The confusing application, the court noted, was at least part of the reason for rejecting the doctrine. The court then opined that the procedural misjoinder doctrine was "an improper expansion of the scope of federal diversity

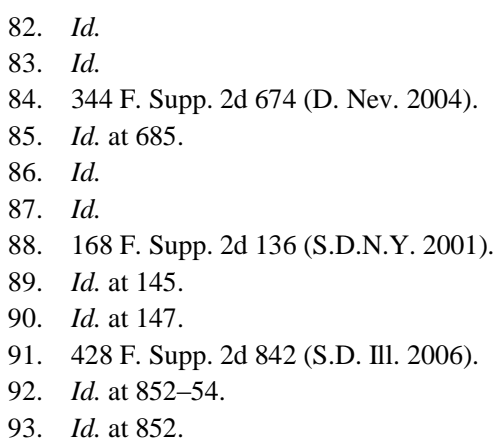


jurisdiction by the federal courts." ${ }^{94}$ Accordingly, the court rejected the doctrine citing both its confusing application and its overstep of the federal courts' jurisdiction.

Finally, other circuit courts have not helped to clarify the doctrine as adopted in Tapscott. The Ninth Circuit in California Dump Truck Owners Association v. Cummins Engine Company, ${ }^{95}$ for example, "assumed without deciding, that [the Ninth Circuit] would accept the doctrine[] of [procedural misjoinder]." ${ }^{, 96}$ In that case, several truck companies filed an action against several engine manufacturers in California state court. ${ }^{97}$ They alleged that several of the diesel engines that they had purchased were faulty. All of the plaintiffs, except one, were citizens of California and diverse from the defendants. ${ }^{98}$ In response to the engine manufacturers' argument that the non-diverse plaintiff had been egregiously misjoined, the court concluded that there seemed to be "some connection or nexus between the claims of the nondiverse plaintiff and the claims of the diverse plaintiffs." joinder of the non-diverse plaintiff "was not so improper as to be considered egregious, thereby justifying ignoring [the non-diverse plaintiff's] presence in the case." " 100 The Ninth Circuit, then, seemed to say that if there is some connection between the plaintiffs' claims, the misjoinder is not egregious.

In concluding that the plaintiffs shared "some connection," the Ninth Circuit cited In re Diet Drugs. ${ }^{101}$ In that case, however, all of the plaintiffs alleged to have ingested a similar drug. ${ }^{102}$ Arguably, then, the plaintiffs in that case also shared some connection. Therefore, it was unclear from the Ninth Circuit's decision what kind of misjoinder was egregious and what type of claims constituted some connection between the plaintiffs. Ultimately, Tapscott's ambiguous standard needed clarification. And the Eighth Circuit had the opportunity to weigh in on the doctrine in Prempro.

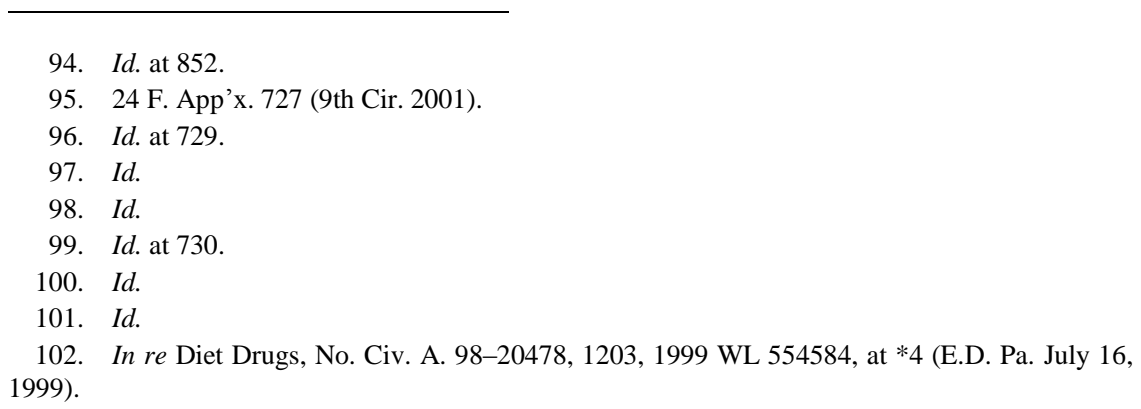


C. In re Prempro Products Liability Litigation: A Reference Point Case in the Development of Procedural Misjoinder

In July of 2008, 123 plaintiffs filed three lawsuits against multiple manufacturers of hormone replacement therapy (HRT) drugs. ${ }^{103}$ The plaintiffs alleged that HRT had caused them or their family members to develop breast cancer. ${ }^{104}$ The plaintiffs filed their state law claims in three separate lawsuits, which were later consolidated. ${ }^{105}$

In the Kirkland suit, 57 plaintiffs brought suit against 11 defendants. ${ }^{106}$ The plaintiffs claimed HRT drugs manufactured by one of the 11 defendants had caused their injury. ${ }^{107}$ Fourteen of the plaintiffs were citizens of the same state as at least one of the defendants. ${ }^{108}$ That is, a plaintiff and a defendant were citizens of the same state; the plaintiff, however, was not necessarily suing that particular defendant. ${ }^{109}$ Only three of the 14 plaintiffs sued the particular defendant that was a citizen of their state. ${ }^{110}$

In the Allen suit, 60 plaintiffs alleged they had developed breast cancer as a result of the HRT drugs manufactured by at least one of the eight defendants. ${ }^{111}$ Although five of the plaintiffs were citizens of the same state as at least one defendant, only three asserted claims against the defendants from their same state. ${ }^{112}$

Then in the Jasperson suit, six plaintiffs sued six defendants. ${ }^{113}$ One of the plaintiffs was from the same state as one of the manufacturers. ${ }^{114}$ In total, 18 plaintiffs were citizens of the same state as at least one of the defendants. ${ }^{115}$ Only six plaintiffs actually asserted claims against manufacturers who were citizens of their same state. ${ }^{116}$

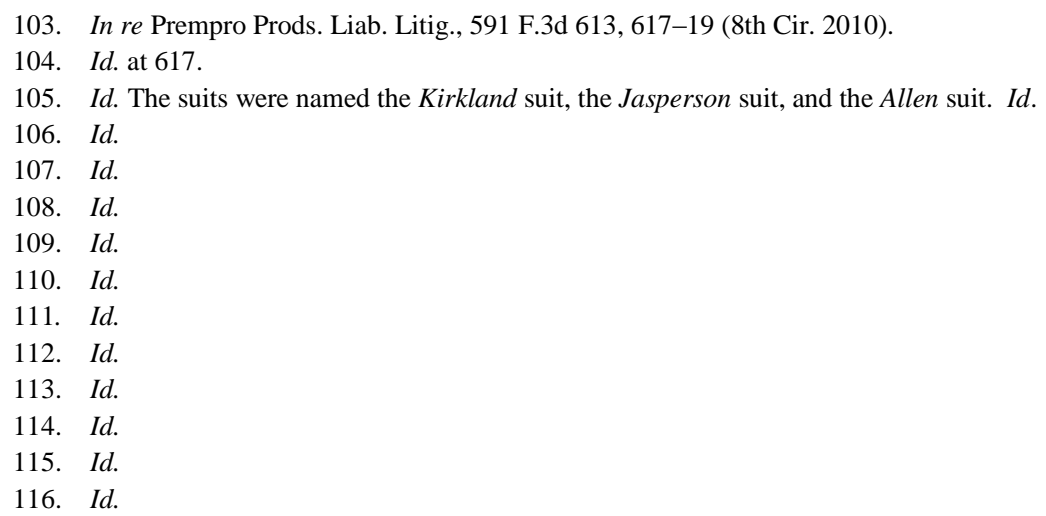


The plaintiffs filed their claims in Minnesota state court. ${ }^{117}$ The defendants then removed the cases to the federal court in the District of Minnesota and argued that complete diversity existed because the plaintiffs' claims were egregiously misjoined. ${ }^{118}$ In other words, the defendants asked the court to apply the procedural misjoinder doctrine. The plaintiffs filed motions to remand to state court asserting that the federal court lacked jurisdiction because the parties were not completely diverse. ${ }^{119}$ Before the federal court in the District of Minnesota made a ruling, however, the cases came before the United States Judicial Panel on Multidistrict Litigation (MDL) and the cases were transferred to the Eastern District of Arkansas, which handled the MDL. ${ }^{120}$

The Eastern District of Arkansas, the MDL court, then ruled on the motions to remand. ${ }^{121}$ The MDL court found that the plaintiffs had been misjoined and noted "MDL courts have repeatedly held that misjoined plaintiffs will not defeat diversity jurisdiction." "22 Thus, the court denied the motion to remand for the diverse parties and granted the motion for the non-diverse parties. ${ }^{123}$ On appeal, the Eighth Circuit reversed, neither accepting nor rejecting the procedural misjoinder doctrine. ${ }^{124}$ However, the court determined that even if it accepted the doctrine, the misjoinder was not so egregious as to warrant its application. ${ }^{125}$

Prempro became a reference point in the development of the procedural misjoinder doctrine, in part because the Eighth Circuit was only the second federal appellate court to address it ${ }^{126}$ and in part because the court failed to define the egregiousness standard. In addition, the facts in Prempro were typical of later cases that applied procedural misjoinder. ${ }^{127}$

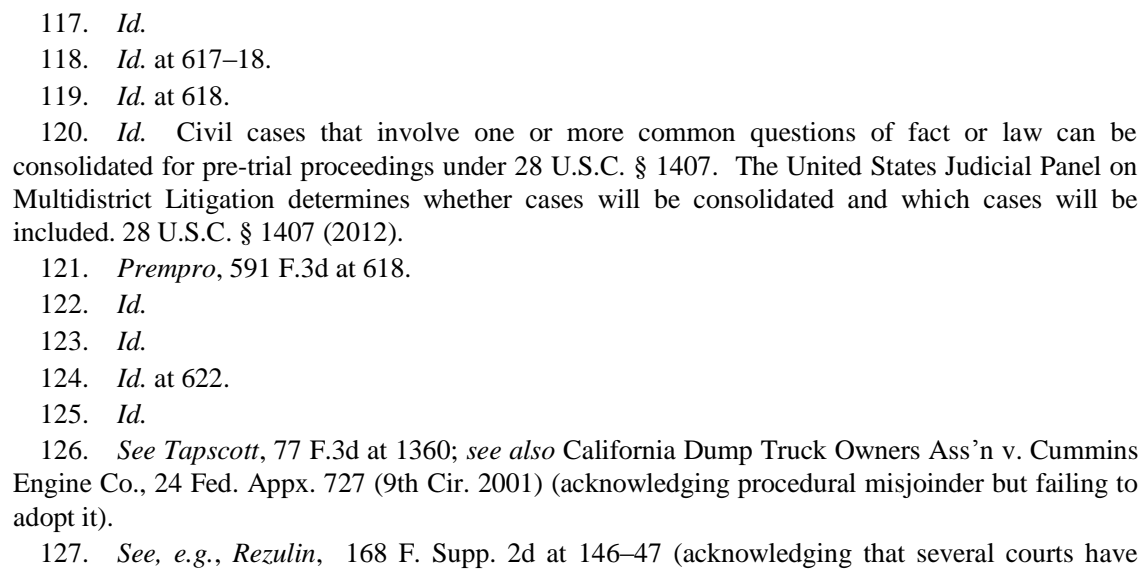
consolidated for pre-trial proceedings under 28 U.S.C. $\$ 1407$. The United States Judicial Panel on Multidistrict Litigation determines whether cases will be consolidated and which cases will be included. 28 U.S.C. $\$ 1407$ (2012).

121. Prempro, 591 F.3d at 618.

122. Id.

123. Id

124. Id. at 622 .

125. Id.

126. See Tapscott, 77 F.3d at 1360; see also California Dump Truck Owners Ass'n v. Cummins Engine Co., 24 Fed. Appx. 727 (9th Cir. 2001) (acknowledging procedural misjoinder but failing to adopt it).

127. See, e.g., Rezulin, 168 F. Supp. 2d at 146-47 (acknowledging that several courts have 


\section{Current State of Procedural Misjoinder}

Courts, however, have continued to struggle to make sense of the procedural misjoinder doctrine. Tapscott concluded that the misjoinder before it was egregious, ${ }^{128}$ while Prempro concluded that the misjoinder before it was not as egregious as the one in Tapscott, ${ }^{129}$ but neither court articulated a clear standard to determine when a misjoinder is egregious. Some district courts determined that Prempro's interpretation all but eliminated the requirement that the plaintiffs' claims must arise out of the same transaction or occurrence. ${ }^{130}$ Other district courts have heavily criticized the Eighth Circuit's analysis but found ways to distinguish it. ${ }^{131}$

So, the doctrine today remains muddled. When district courts have applied the doctrine, they have stressed different facts in their conclusions that a misjoinder is egregious. Litigants are left knowing that egregious misjoinder probably cannot defeat removal. But just what constitutes egregiousness is anyone's guess. However, some patterns have begun to emerge, and as this comment argues, a uniform standard may be within sight.

\section{ANALYSIS}

Although the development of the procedural misjoinder doctrine has been confusing, it is a necessary tool to allow courts to address the unrelated party problem in diversity jurisdiction. The Eighth Circuit in Prempro had the opportunity to clarify this confusing doctrine, but missed its opportunity. Other circuit courts considering the procedural misjoinder doctrine can avoid making the same mistake by acknowledging the increasing importance for clarification of the misjoinder doctrine. By adopting a multi-factor test such as the one laid

applied procedural misjoinder in the context of remand petitions in multi-plaintiff pharmaceutical actions).

128. Tapscott, 77 F.3d at 1360 .

129. Prempro, 591 F.3d at 622.

130. T.F. ex rel. Foster v. Pfizer, Inc., No 4:12CV1221 CDP, 2012 WL 3000229, at*3 (E.D. Mo. 2012) (holding that in light of Prempro the "[p]laintiffs claims need not arise from the same transaction or occurrence").

131. Infra section III.B.3. See In re Fosamax (Alendronate Sodium) Prods. Liab. Litig. (No. II), No. 11-3045, 2012 WL 1118780, at*5 (D.N.J. Apr. 3, 2012) (noting that, unlike Prempro, in the case before it there was evidence that the plaintiffs joined their claims to avoid diversity jurisdiction); In re Propecia (Finasteride) Prod. Liab. Litig., No. 12-MD-2331 (JG)(VVP), No. 12CV-2049 (JG)(VVP), 2013 WL 3729570, at *13 (E.D.N.Y. May 17, 2013) ("The plaintiffs here also do not allege the same type of discrete injury alleged by the plaintiffs in Prempro."). 
out in this comment, courts will ensure that the doctrine is neither confusing nor an inappropriate expansion of diversity jurisdiction.

\section{A. Why Procedural Misjoinder is Necessary}

Procedural misjoinder is a necessary and helpful doctrine because it tackles a common difficulty faced by courts. The misjoinder of unrelated parties to prevent removal to federal court is an "enduring problem." 132 Generally, both state and federal rules of procedure allow for liberal joinder of parties. ${ }^{133}$ The purpose for allowing the joinder of parties is to promote trial convenience and expedite the determination of the disputes. ${ }^{134}$ But the joinder of unrelated parties does not promote trial convenience and expedite the determination of the disputes. ${ }^{135}$ To the contrary, unrelated parties joined in a single lawsuit present individual issues that "obstruct and delay the adjudication process."136 Thus, misjoinder of unrelated parties is problematic because it does not serve the purposes of the joinder rules.

The joinder of unrelated parties is also problematic because it allows a party to manufacture a non-diverse lawsuit by manipulating the joinder rules. Federal courts and statues generally disfavor tactics that avoid federal jurisdiction on a technicality. ${ }^{137}$ Indeed, this is the exact problem that the Class Action Fairness Act (CAFA) addressed. ${ }^{138}$ CAFA relaxed federal courts' jurisdictional requirements for class actions to make it more difficult for plaintiffs to join non-diverse parties and avoid federal

132. Hines \& Gensler, supra note 5, at 809.

133. WILliams \& CAMPF, supra note 13, at $\S 5: 26$ (explaining that the Supreme Court has interpreted the joinder rules liberally).

134. See id. ("The judicial justification for liberal joinder is efficiency."); WRIGHT, supra note $40, \S 1652$.

135. Fosamax, 2012 WL 111878780 , at *5.

136. In re Diet Drugs Prods. Liab. Litig., No. Civ. A. 98-20478, 1999 WL 554584, at *3 (E.D. Pa. July 16, 1999).

137. In re Propecia (Finasteride) Prod. Liab. Litig., No. 12-MD-2331 (JG)(VVP), No. 12-CV2049 (JG)(VVP), 2013 WL 3729570, at *8 (E.D.N.Y. May 17, 2013); see also Mississippi ex rel. Hood v. AU Optronics Corp., 134 S. Ct. 736, 744 (2014) (noting that the mass action provision of CAFA ensures that the "relaxed jurisdictional rules for class actions cannot be evaded"); Wecker v. Nat'l Enameling \& Stamping Co., 204 U.S. 176, 182-83 (1907) (“[T]he Federal courts may, and should, take such action as will defeat attempts to wrongfully deprive parties entitled to sue in the Federal courts of the protection of their right to tribunals."); Rosenthal, supra note 43, at 73 (noting that while tactical devices to defeat federal jurisdiction are not expressly prohibited by statute, the courts apply various approaches to discern when parties wrongfully evade federal jurisdiction).

138. Mississippi ex rel. Hood, 134 S. Ct. at 744. 
court. ${ }^{139}$ So, even Congress has recognized that allowing manipulation of the rules to avoid jurisdiction is bad policy.

Rejection of the procedural misjoinder doctrine would leave the problem unaddressed. The permissive joinder of unrelated parties would not only fail to promote trial convenience and expedite the determination of the disputes but would, in fact, frustrate that very purpose. Moreover, parties could manufacture a non-diverse lawsuit by manipulating the joinder rules. Therefore, parties should not be able to thwart removal to federal court by manipulating the joinder rules and procedural misjoinder should be adopted to address the problem.

\section{B. Prempro: A Missed Opportunity}

\section{An Ideal Opportunity to Clarify}

In Prempro, the Eighth Circuit missed an ideal opportunity to adopt and clarify the procedural misjoinder doctrine. First, Prempro represented a common scenario in which procedural misjoinder arises. Moreover, unlike the court in Tapscott, the Eighth Circuit had nearly a decade of case law to consider. Finally, the accumulated case law reflected an inconsistent understanding by lower courts that could have been clarified.

Prempro represented a common scenario in which procedural misjoinder arises. In the context of multi-plaintiff pharmaceutical actions, courts often deal with "clearly improper" 140 but not "entirely unrelated"141 joinders of parties. The plaintiffs have often taken the same type of drug, and there may be common issues of law or fact. ${ }^{142}$ Recognizing the slight connection, not all courts deem the misjoinders "egregious." 143 Yet, they recognize the "express purpose of blocking removal." When pointing out the mixed reactions of the district

\footnotetext{
139. Id.; 28 U.S.C. $§ 1332$ (2012).

140. Propecia, 2013 WL 3729570 , at $* 5$.

141. In re Prempro Prods. Liab. Litig., 591 F.3d 613, 621 (8th Cir. 2010).

142. Id. at 620-21.

143. See, e.g., In re Trasylol Prods. Liab. Litig., 754 F. Supp. 2d 1331, 1337 (S.D. Fla. 2010) (holding that the misjoinder was not egregious because the plaintiffs all took the same drug manufactured by the defendant); Lovett v. Pfizer Inc., No. 4:14-CV-458 CEJ, 2014 WL 1244956, at *2 (E.D. Mo. Mar. 26, 2014) ("As this Court has found in several recent cases, the joinder of plaintiffs alleging injury from a single drug is not 'egregious,' because common issues of law and fact connect plaintiffs' claims." (citations omitted)).

144. Hines \& Gensler, supra note 5, at 809; see, e.g., In re Yasmin \& Yaz (Drospirenone) Mktg., Sales Practices \& Prods. Liab. Litig., 779 F. Supp. 2d 846, 856 (S.D. Ill. 2011) (recognizing
} 
courts, the Eighth Circuit cited In re Diet Drugs ${ }^{145}$ and Rutherford ${ }^{146}$ cases that came to opposite conclusions and were both multi-plaintiff products-liability actions. ${ }^{147}$ So, not only were the policy concerns apparent in the facts before the Prempro court, but they were also common.

In its decision, the court made no attempt to define the meaning of egregious by addressing the decade and a half of case law that had attempted to apply the Tapscott holding. Instead, the court attempted to define the meaning of egregious by looking only to the facts of Tapscott. ${ }^{148}$ Speaking of Tapscott, the court pointed out that " $[\mathrm{t}]$ he result of the amended complaints and joinder under Rule 20 was to create two distinct groups of plaintiffs and defendants: the non-diverse 'automobile class' and the diverse "merchant class.",149 The court noted that the two Tapscott groups had "no real connection" with each other. ${ }^{150}$ Framing the issue in this manner, the court attempted to define the ambiguous standard by looking only to the facts of Tapscott. However, the Prempro court had an advantage that the Tapscott court did not have-nearly a decade of accumulated case law.

Finally, the case law attempting to apply Tapscott was unclear and in need of clarification. The Prempro court acknowledged the district courts' mixed reactions to the procedural misjoinder doctrine. ${ }^{151}$ The court recognized that some courts had appreciated the need to protect the statutory right to removal, while others had rejected the doctrine because of its ambiguity and expansion of federal diversity jurisdiction. ${ }^{152}$ So, the court acknowledged the competing policy concerns and the need for clarity. Accordingly, as only the second circuit court to consider procedural misjoinder, the Eighth Circuit missed an ideal opportunity to clarify the doctrine and other circuit courts should avoid repeating the mistake.

\footnotetext{
that the structuring of the lawsuits was "deliberate and employed for the purpose of avoiding removal to federal court").

145. No. 98-20478, 1999 WL 554584 (E.D. Pa. July 16, 1999).

146. Rutherford v. Merck \& Co., 428 F. Supp. 2d 842 (S.D. Ill. 2006).

147. In re Diet Drugs, 1999 WL 554584, at *3 (applying procedural misjoinder because the misjoinder deprived defendants of the right to removal); Rutherford, 428 F. Supp. $2 \mathrm{~d}$ at 851 (holding that procedural misjoinder is an improper expansion of federal jurisdiction).

148. In re Prempro Prods. Liab. Litig., 591 F.3d 613, 620-21 (8th Cir. 2010).

149. Prempro, 591 F.3d at 621.

150. Id. at 623 .

151. Id.

152. Id
} 


\section{The Eighth Circuit's Application of Procedural Misjoinder}

The Eighth Circuit did not expressly reject or accept the doctrine; instead, the court declined to weigh in on the doctrine's propriety. ${ }^{153}$ Yet, the court went on to conclude that the misjoinder was not so egregious as to constitute procedural misjoinder. If this was meant as an implicit acknowledgment of the egregious standard, the court should have applied it clearly and explained its application. Moreover, the court should have addressed the accumulated case law to clarify the standard.

The Eighth Circuit should have expressly adopted the procedural misjoinder doctrine; yet, it "ma[de] no judgment on the propriety of the doctrine." 154 The court, however, was presented with a common factual scenario faced by district courts. District courts are often confronted with the joinder of unrelated parties in multi-plaintiff pharmaceutical actions. ${ }^{155}$ And the policy concerns are apparent in this common scenario. Had the court considered the policy concerns, it may have cautiously adopted the procedural misjoinder doctrine as necessary. Therefore, the Eighth Circuit erred by refusing to expressly adopt procedural misjoinder as a viable doctrine.

In addition, if the court's analysis was meant as an application of procedural misjoinder, it should have clearly defined the meaning of egregious. After refusing to expressly adopt or reject the procedural misjoinder doctrine the court continued, "we conclude that even if we adopted the doctrine, the plaintiffs' alleged misjoinder in this case is not so egregious as to constitute [procedural] misjoinder." 156 The court explained that the parties were not entirely unrelated, so they were not egregiously misjoined. The court seemed to conclude that the plaintiffs' claims were related. However, this conclusion was a result of an overly broad interpretation of the "transaction" requirement under Rule 20 of the Federal Rules of Civil Procedure.

The court's broad interpretation of Rule 20's "transaction" requirement was not consistent with the rule's purpose, so it is unclear why the court interpreted it so broadly. To determine whether the misjoinder was egregious, the court looked to the procedure by which

\footnotetext{
153. Id. at 622 .

154. Id.

155. See, e.g., In re Propecia (Finasteride) Prod. Liab. Litig., No. 12-MD-2331 (JG)(VVP), No. 12-CV-2049 (JG)(VVP), 2013 WL 3729570, at *6-8 (E.D.N.Y. May 17, 2013); see also discussion supra Part III.B.1.

156. Prempro, 591 F.3d at 622.
} 
plaintiffs may be joined. ${ }^{157}$ Although there is some question as to whether the state or federal rules of civil procedure should govern, ${ }^{158}$ the court concluded that it would make little difference to the analysis. Rule 20(a) allows a party to be joined if it asserts a claim "arising out of the same transaction, occurrence, or series of transactions or occurrences" and "any question of law or fact common to the plaintiffs will arise in the action." 159 The court then noted that the word transaction has a "flexible meaning" and that all "logically related" events would satisfy the test for joinder under Rule $20 .{ }^{160}$

Under this definition of transaction, the court concluded that the plaintiffs' claims arose from a series of transactions between pharmaceutical manufacturers and individuals that used their product. ${ }^{161}$ Moreover, the court accepted the plaintiffs' argument that their claims were logically related because each had developed breast cancer as a result of some conduct of the defendant. While applying this extremely loose definition of transaction the court failed to consider an important piece of the analysis. Transaction should be "read as broadly as possible whenever doing so is likely to promote judicial economy."162

The complaints in Prempro joined different plaintiffs who were prescribed HRT drugs at different times by different doctors in different states. $^{163}$ Instead of promoting judicial economy, the joinder of these plaintiffs into one suit would frustrate that very purpose. Each plaintiff would have individual issues of causation and damages. The complex question would arise of which state laws would apply to each of the plaintiffs' claims. Hence, the joinder of these plaintiffs into one lawsuit did not promote judicial economy. True, the term "transaction" should be read broadly, but only when doing so "is likely to promote judicial economy." 164 Therefore, it is unclear why the court interpreted Rule 20 so broadly because the joinder did not promote judicial economy. Yet,

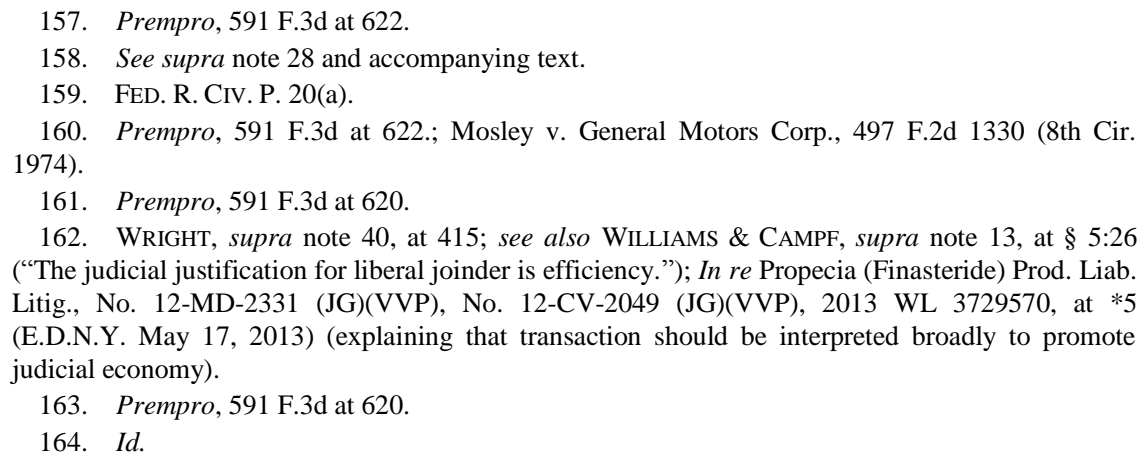


the court seemed to suggest that the same transaction requirement was satisfied, or at least not egregiously misused.

Like the Eleventh Circuit in Tapscott, the Eighth Circuit did little to set out what conduct would be deemed egregious. Instead, it concluded that the joinder before it did not constitute an egregious misjoinder because the parties were not entirely unrelated. ${ }^{165}$ Ultimately, the court's attempt to apply the procedural misjoinder doctrine was unclear. And the court's application resulted in confusion for district courts.

\section{Reaction to Prempro}

In re Propecia (Finasteride) Product Liability Litigation ${ }^{166}$ exemplifies the confusion among lower courts created by the Prempro court's broad definition of transaction. As the Propecia court explained: "the [Prempro] court essentially ignored the 'same transaction' prong of the joinder inquiry. Although the court noted that the plaintiffs' claims all arose from a series of transactions, the court made no determination that their claims arose from the same transaction or series of transactions." not provide any specificity about the conduct of the defendant. Therefore, "the [Prempro] court appears to have determined that the transactions were 'logically related' to each other, and thus satisfied the 'same transaction' prong of the joinder analysis, not because of any similarity in the defendants' conduct, but only because the plaintiffs had all suffered the same injury."168 "The Propecia court stressed that Prempro all but eliminated the "same transaction" requirement of Rule 20.

Still, the Propecia court found that that the plaintiffs before it had been egregiously misjoined even under the Eighth Circuit's analysis because the plaintiffs did not provide enough specificity of their injuries to support their joinder. ${ }^{169}$ In Propecia, the plaintiffs alleged to have developed sexual dysfunctions "whose cause and manifestation [would] be unique to each individual." 170 The court noted that in Prempro, the

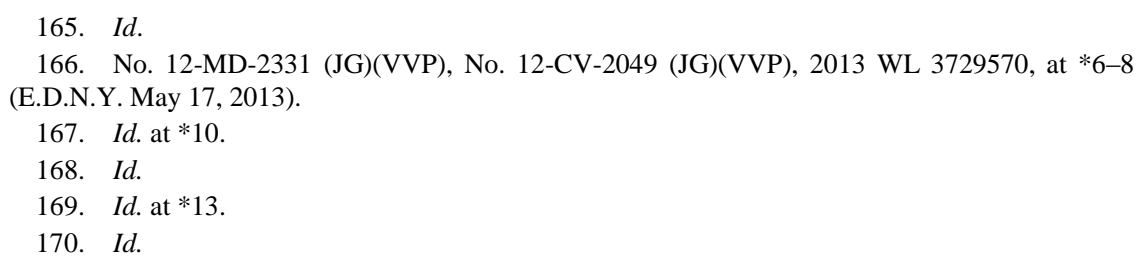


plaintiffs had all alleged the same type of discrete injury. So, the Propecia court concluded that the joinder of the plaintiffs before it was not supported by the pleadings because the court could not determine whether their claims were "logically related." 171 Accordingly, the misjoinder of the plaintiffs was held to be egregious and warranted application of the procedural misjoinder doctrine.

Meanwhile, in In re Fosamax (Alendronate Sodium) Products Liability Litigation No. II, ${ }^{172}$ the court concluded that the misjoinder in Prempro was not egregious because there was no evidence that the plaintiffs joined their claims to avoid diversity jurisdiction. ${ }^{173}$ In Fosamax, the plaintiffs' allegations on the complaint were vague. In that case, several plaintiffs joined together to sue several drug manufacturers in Missouri state court. ${ }^{174}$ The plaintiffs alleged that the defendants' products had caused them to suffer a long bone fracture. ${ }^{175}$ The plaintiffs were from many different states and asserted several state law claims. ${ }^{176}$ In their complaint, they alleged that the defendants concealed the risks of their products while at the same time exaggerating the benefits. ${ }^{177}$ However, the plaintiffs were imprecise in naming the defendants. ${ }^{178}$ In other words, although it was clear from the face of the complaint that some plaintiffs alleged a cause of action against some of the defendants, it was not clear which plaintiffs claimed to have suffered injury by which defendants. ${ }^{179}$ This made it impossible for the court to determine which plaintiffs were truly non-diverse from the defendants. ${ }^{180}$ The court concluded that this imprecise pleading tactic was evidence that the plaintiffs had attempted to avoid diversity jurisdiction. So, under Prempro's analysis, the Fosamax court found the misjoinder was egregious and warranted the application of procedural misjoinder.

Both the Propecia and Fosamax courts struggled to understand just what is egregious under the Eighth Circuit's analysis. Although both courts criticized the reasoning of the opinion, both ultimately strained to find a misjoinder egregious under the Eighth Circuit's decision.

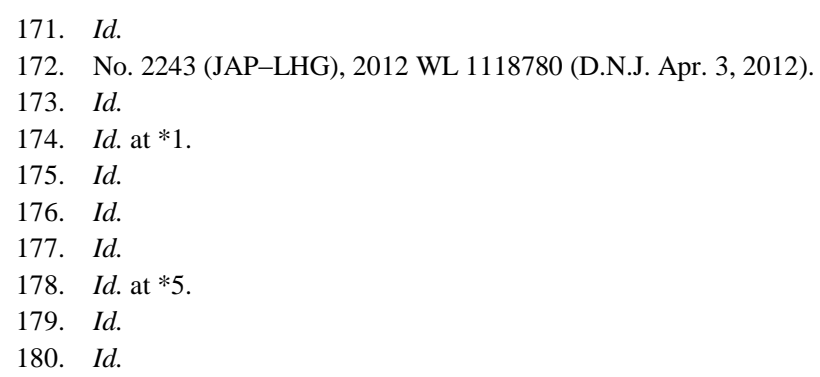




\section{Now is the Time for Clarification}

Now is the ideal time for courts to clarify the misjoinder doctrine because the problem of unrelated joinder of parties is likely to intensify following the passage of the Class Action Fairness Act (CAFA) and the inability of the circuit courts to clarify the joinder doctrine.

CAFA, passed by Congress in 2005, attempted to address the problem of joinder of unrelated parties in multi-plaintiff litigation. ${ }^{181}$ The new law loosened the diversity jurisdiction requirements for class actions. ${ }^{182}$ Rather than requiring complete diversity, only minimal diversity is required in a class action. ${ }^{183}$ Moreover, the individual claims need not be over $\$ 75,000$, but rather, the aggregate amount of the claims must exceed \$5 million. ${ }^{184}$ Although, "Congress' overriding concern in enacting CAFA was with class actions," it also addressed multi-plaintiff actions that were not brought under the class action device-what the statute refers to as mass actions. ${ }^{185}$

CAFA allows defendants to remove mass actions to federal court. "Mass action" as defined by the statute is "any civil action . . . in which monetary relief claims of 100 or more persons are proposed to be tried jointly on the ground that the plaintiffs' claims involve common questions of law or fact."186 CAFA thus altered the traditional diversity jurisdiction requirements for mass actions. CAFA allows the mass action to be removed to federal court when there is only minimal diversity, rather than complete diversity. ${ }^{187}$

As the Supreme Court has explained: "The mass action provision thus functions largely as a backstop to ensure that CAFA's relaxed jurisdictional rules for class actions cannot be evaded by a suit that names a host of plaintiffs rather than using the class device."188 So, Congress anticipated that plaintiffs would push back on CAFA's relaxed jurisdictional requirements by joining a large amount of plaintiffs in one state court suit. To deal with this, Congress enacted the mass action provision, enabling defendants to remove suits when more than 100

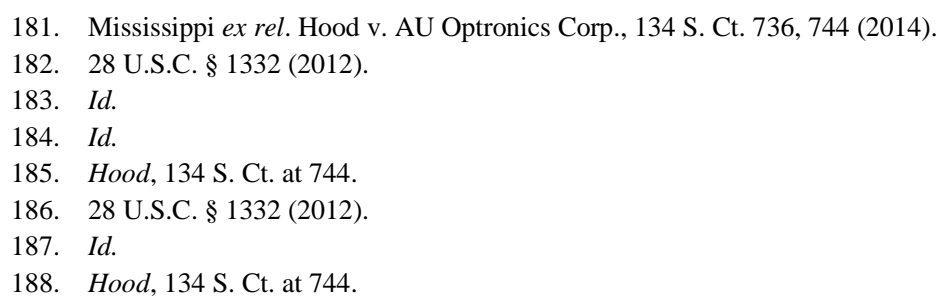


plaintiffs are joined together in state court.

Seeking to avoid the removal jurisdiction of the federal court, some plaintiffs file multiple lawsuits in state courts - all with less than 100 plaintiffs. ${ }^{189}$ So, the problem of joinder of unrelated parties gets worse because no matter whether the plaintiffs have any "real connection" they join together in state court and strategically structure the pleadings to avoid removal. Absent procedural misjoinder district courts are likely to see many lawsuits filed with just under 100 plaintiffs, all of whom may not have a reason to join together except to defeat removal to federal court.

Finally, other circuit courts contributed little to clarifying the procedural misjoinder standard. For example, in Lafalier v. State Farm Fire and Casualty Co. ${ }^{190}$ the Tenth Circuit acknowledged that "[t]here may be good reasons to adopt procedural misjoinder . . . [b]ut we need not decide that issue today." Circuit noted "it might be concluded that misjoinder of plaintiffs should not be allowed to defeat diversity jurisdiction." 192 And, as noted above, the Ninth Circuit "assumed without deciding" that they would accept the doctrine. ${ }^{193}$ As a whole, the circuit court cases have been unhelpful in clarifying the standard of procedural misjoinder while at the same time seeming to be receptive to adopting it.

Currently, therefore, the timing for a clarification of the procedural misjoinder doctrine would be ideal as courts struggle to make sense of Prempro, just as they struggled with Tapscott. Moreover, the problem of unrelated parties joined in state court is likely to become more common in light of CAFA. Finally, to date, circuit courts have been entirely unhelpful in clarifying the procedural misjoinder doctrine. Accordingly, the time for clarification is now.

\section{A Solution: A Four Factor Test}

A uniform standard, narrowly tailored to its common application, would ensure a simpler application of the doctrine and prevent federal

189. See, e.g., In re Fosamax (Alendronate Sodium) Prods. Liab. Litig., No. 2243 (JAP-LHG), 2012 WL 1118780, at *5 (D.N.J. Apr. 3, 2012) (ninety-one plaintiffs joined together to sue in state court); In re Trasylol Prods. Liab. Litig., 754 F. Supp. 2d 1331, 1332 (S.D. Fla. 2010) (ninety-nine plaintiffs joined together to sue in Missouri state court—only six had any connection with Missouri).

190. 391 F. App'x 732 (10th Cir. 2010).

191. Id. at 739 .

192. In re Benjamin Moore \& Co., 309 F.3d 296, 298 (5th Cir. 2002).

193. Cal. Dump Truck Owners Ass'n v. Cummins Engine Co., 24 F. App'x 727 (9th Cir. 2001). 
courts from overstepping their jurisdiction. Courts have generally criticized procedural misjoinder for two reasons: 1) its complexity, and 2) the danger of inappropriately expanding the federal court's diversity jurisdiction. However, a uniform standard would allow for a simpler application; and, narrowly tailored, the doctrine is only an extension of fraudulent joinder principles.

Courts rightly criticize procedural misjoinder's egregious standard as confusing and difficult to apply. ${ }^{194}$ What constitutes an egregious misjoinder is difficult to define because it depends heavily on the facts. Though difficult to define, guideposts can help courts remain consistent in their application. ${ }^{195}$ Implementing a multi-factor test would allow courts to address the competing policy concerns and allow for a simpler application.

Moreover, a narrowly tailored procedural misjoinder doctrine is an appropriate expansion of fraudulent joinder principles. ${ }^{196}$ Indeed, as the Eleventh Circuit articulated in Tapscott, "[m]isjoinder may be just as fraudulent as the joinder of a resident defendant against whom a plaintiff has no possibility of a cause of action."197 A party with "no real connection with the controversy" cannot defeat diversity jurisdiction simply by asserting a claim, which it does not have. ${ }^{198}$ The acceptance of procedural misjoinder can be seen as merely an extension of this principle. Just as a party cannot defeat diversity jurisdiction by asserting a meritless claim, a party cannot defeat diversity jurisdiction joining parties who are not truly part of the controversy. Thus, procedural misjoinder is not an inappropriate expansion of diversity jurisdiction, but, instead, a necessary corollary of fraudulent joinder.

Implementing a multi-factor test would allow courts to address the competing policy concerns and allow for a simpler application of the

194. See, e.g., Osborn v. Metropolitan Life Ins. Co., 341 F. Supp. 2d 1123, 1127 (E.D. Cal. 2004) ("[T]he last thing the federal courts need is more procedural complexity."); Geffen v. Gen. Elec. Co., 575 F. Supp. 2d 865, 871 (N.D. Ohio 2008) (refusing to apply procedural misjoinder because of its complexity).

195. Guideposts would allow courts to clarify procedural misjoinder rather than further complicate the doctrine. See WRIGHT, supra note 40, $\$ 3723$ ("The complexity is increased if the Eleventh Circuit's admonition that not all procedural misjoinder arises to the level of fraudulent joinder is accepted and because numerous additional decisions will be needed to clarify the distinction.").

196. See Greene v. Wyeth, 344 F. Supp. 2d 674, 684-85 (applying the corresponding fraudulent joinder standard to procedural misjoinder); In re Yasmin \& Yaz (Drospirenone) Mktg., Sales Practices \& Prods. Liab. Litig., 779 F. Supp. 2d 846, 854 (S.D. Ill. 2011).

197. Tapscott v. MS Dealer Serv. Corp., 77 F.3d 1353, 1360 (11th Cir. 1996).

198. Id. 
procedural misjoinder doctrine. And although the development of the procedural misjoinder doctrine has been inconsistent, lower courts have helped contribute to a factor-based test. Accordingly, courts applying the procedural misjoinder doctrine should consider the following factors: 1) whether the misjoinder frustrates the purpose of permissive joinder; ${ }^{199} 2$ ) whether the misjoinder meets the test for fraudulent joinder; ${ }^{200} 3$ ) whether it is clear which plaintiffs have claims against which defendants; ${ }^{201}$ and 4 ) whether the pleadings are sufficiently specific to support the joinder. ${ }^{202}$

\section{Frustrating the Purpose of the Joinder Rules}

Courts should consider whether the misjoinder frustrates the purpose of permissive joinder, which is to promote trial convenience and expedite the determination of disputes. ${ }^{203}$ In Fosamax the court illustrated why this factor would be helpful, particularly in multi-plaintiff pharmaceutical actions. $^{204}$ In Fosamax, 91 plaintiffs from 28 different

199. See In re Fosamax Prods. Liab. Litig., No. 2243 (JAP-LHG), 2012 WL 1118780, at *5 (D.N.J. Apr. 3, 2012) (noting that the misjoinder frustrated the purpose of the joinder rules); Sutton v. Davol, Inc., 251 F.R.D. 500, 505 (E.D. Cal. 2008) (applying procedural misjoinder "to preserve the interests of judicial expediency and justice").

200. See Conk v. Richards \& O’Neil, LLP, 77 F. Supp. 2d 956, 971 (S.D. Ind. 1999) (describing procedural misjoinder as a type of fraudulent joinder); see also Jeff Fisher, Everybody Plays the Fool, Sometimes; There's No Exception to the Rule: Procedural Misjoinder Is Not An Exception to the Voluntary-Involuntary Rule, 60 BAYLOR L. REV. 993, 1008-09 (2008) (“A few courts and commentators have suggested what seems like a better test for procedural misjoinder: the reasonable basis test used to identify fraudulent joinder."); contra Parsons, supra note 26, at 65 (arguing that procedural misjoinder is an intrusion into state law by federal courts).

201. See In re Propecia (Finasteride) Prod. Liab. Litig., No. 12-MD-2331 (JG)(VVP), No. 12CV-2049 (JG)(VVP), 2013 WL 3729570, at *6-8 (E.D.N.Y. May 17, 2013) (concluding that the misjoinder was egregious because diversity was not apparent from the face of the complaint because of the plaintiffs' pleading tactics).

202. See In re Fosamax Prods. Liab. Litig., No. 2243 (JAP-LHG), 2012 WL 1118780, at *5 (D.N.J. Apr. 3, 2012) (holding that the misjoinder was egregious because the court could not conclude by the plaintiffs' allegations if they shared any logical connection); contra Atwell v. Boston Scientific Corp., No. 4:12-CV-2363 (CEJ), 2013 WL 136471, at *3 (E.D. Mo. Jan. 10, 2013) ("Defendant argues the Court should find egregious misjoinder because plaintiffs fail to plead specific facts regarding their underlying medical conditions or the precise injuries they allege they sustained from defendant's products. These facts were omitted, defendant states, to conceal the absence of a common question of fact. Furthermore, defendant argues, there are reasons to believe that several of the plaintiffs' claims are time-barred. In light of Prempro, the Court declines to find that these possible deficiencies in pleading amount to bad faith misjoinder.").

203. See Fosamax, 2012 WL 1118780 , at $* 5$ (noting that the misjoinder frustrated the purpose of the joinder rules); Propecia, 2013 WL 3729570, at $* 5$ (explaining that Rule 20 should be interpreted broadly to promote judicial economy); see also WRIGHT, supra note 40; WILLIAMS \& CAMPF, supra note 13, § 5:26 ("The judicial justification for liberal joinder is efficiency.").

204. Fosamax, 2012 WL 1118780 , at $* 4$. 
states filed an action in Missouri state court against multiple drug manufacturers. ${ }^{205}$ Although the plaintiffs' claims emanated from a general failure to warn theory, they asserted numerous state law claims. ${ }^{206}$ Their claims were "based upon various state law products liability theories, including, inter alia, defective design, negligence, fraud, misrepresentation, breach of express and implied warranties, and loss of consortium." 207 So, the various claims of 91 different plaintiffs were to be decided according to 28 different state laws. Applying the law of 28 states to 91 plaintiffs does not promote trial convenience or expedite the determination of disputes. Instead, it frustrates that very purpose. $^{208}$

The court noted, specifically, that the "joinder of plaintiffs in a drug product liability case in no way promotes judicial efficiency or convenience" not only because of the complexity of applying different state laws but also because of the challenging factual scenarios that such cases often present. ${ }^{209}$ The court then looked to the reasoning in In re Rezulin Products Liability Litigation. ${ }^{210}$ That case also involved multiple plaintiffs seeking to recover from multiple drug manufacturers for product defects. The Rezulin court illustrated why the joinder of unrelated plaintiffs in drug product liability cases frustrates the purpose of the joinder rules:

The plaintiffs . . . allege a defect (or defects) the precise contours of which are unknown and which may have caused different results - not merely different injuries - in patients depending on such variables as exposure to the drug, the patient's physical state at the time of taking the drug, and a host of other known and unknown factors that must be considered at trial with respect to each individual plaintiff. They do not allege that they received Rezulin from the same source or that they were exposed to Rezulin for similar periods of time ... [T]hey do not allege injuries specific to each of them so as to allow the Court to determine how many plaintiffs, if any, share injuries in common. ${ }^{21}$

Indeed, tort cases often involve the complicated tasks of determining causation and damages, especially in multi-plaintiff pharmaceutical

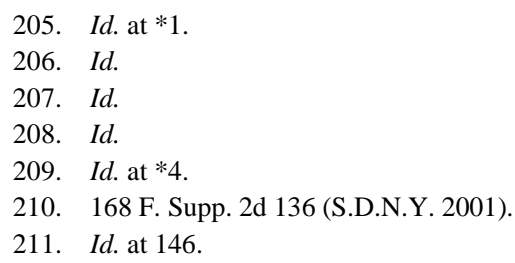


actions. Joining otherwise unrelated plaintiffs in no way makes the tasks easier.

A misjoinder that frustrates the purpose of the joinder rules warrants the application of the procedural misjoinder doctrine. If the joinder rules are not being used to promote efficiency, then they are being used for some other purpose. This inquiry is what has lead courts to quibble over the level of "bad faith," if any, that the party must have. ${ }^{212}$ Considering whether the misjoinder frustrates the purpose of the rules allows a court to avoid the inquiry into the party's motive. Still, it allows the court to determine whether permissive joinder is being used as a tool to defeat diversity jurisdiction and thwart removal to federal court - a purpose that courts have found constitutes egregious misjoinder. ${ }^{213}$ Therefore when applying the procedural misjoinder doctrine, courts should consider whether the misjoinder frustrates the purpose of the joinder rules.

\section{Corresponding Test for Fraudulent Joinder}

Next, courts should consider whether the misjoinder would meet the test for fraudulent joinder. ${ }^{214}$ Some courts and commentators have suggested that the standards for procedural misjoinder and fraudulent joinder should be the same. ${ }^{215}$ For example, in Conk v. Richards \& $O^{\prime} N e i l, L L P,{ }^{216}$ the court explained that the appropriate standard for procedural misjoinder was not provided by the Federal Rules of Civil Procedure, noting: "when [the plaintiff] filed his complaint in the [state court] he was not required to comply with the Federal Rules of Civil Procedure in terms of joinder of parties." 217 Moreover, the court described procedural misjoinder as a type of fraudulent joinder. So, the court concluded, the standard was essentially the same. ${ }^{218}$ Although procedural misjoinder has not been uniformly accepted as a viable

212. See Palmer v. Davol, Inc., No. 07-md-1842-ML, 2008 WL 5377991, at *3 (D.R.I. Dec. 23, 2008) (collecting cases).

213. In re Diet Drugs, No. Civ. A. 98-20478, 1203, 1999 WL 554584, at *4 (E.D. Pa. July 16, 1999).

214. See Percy, supra note 4, at 621-22 (arguing that the corresponding fraudulent joinder standard should apply to procedural misjoinder).

215. See Fisher, supra note 200, at 1008 ("A few courts and commentators have suggested what seems like a better test for procedural misjoinder: the reasonable basis test used to identify fraudulent joinder.”); Conk v. Richards \& O’Neil, LLP, 77 F. Supp. 2d 956, 971 (S.D. Ind. 1999) (describing procedural misjoinder as a type of fraudulent joinder).

216. 77 F. Supp. 2d 956 (S.D. Ind. 1999).

217. Id. at 971 .

218. Id. 
doctrine and warrants different treatment, the corresponding fraudulent joinder standard may be helpful in assuring that federal courts do not overstep their jurisdiction. ${ }^{219}$

Fraudulent joinder has long been accepted as an appropriate exercise of the federal court's jurisdiction. ${ }^{220}$ By considering whether the misjoinder meets the test for fraudulent joinder, courts would address the concern that procedural misjoinder expands the scope of diversity jurisdiction beyond its limits. If the misjoinder meets the test of fraudulent joinder, then jurisdiction would extend no further than already allowed under the fraudulent joinder standard. Procedural misjoinder, then, would only be an extension of the fraudulent joinder doctrine.

Although helpful, the fraudulent joinder standard should not be the sole inquiry because the questions that fraudulent joinder and procedural misjoinder seek to answer are entirely different. Fraudulent joinder asks whether the joined plaintiff even has a valid claim against the defendant. Procedural misjoinder, on the other hand, asks whether the plaintiffs have any reason to be joined in the same suit. Accordingly, the procedural misjoinder standard should not necessarily be identical to the fraudulent joinder standard because they ask different questions.

Therefore, courts should consider whether the misjoinder meets the corresponding test for fraudulent joinder to keep the doctrine from expanding the limited jurisdiction of the federal court.

\section{Which Plaintiffs Have Claims Against Which Defendants}

Courts should then consider whether it is apparent from the face of the complaint if the plaintiffs are truly not diverse from the defendants. ${ }^{221}$ In lawsuits with multiple plaintiffs and multiple defendants it is often unclear which plaintiffs assert claims against which defendants. For example, in Propecia, 54 plaintiffs claimed to have suffered injury as a

219. Courts have criticized the procedural misjoinder doctrine for the danger of federal courts overstepping their jurisdiction. See Moore v. Mobil Oil Corp., 904 F. Supp. 587, 588 (E.D. Tex. 1995) ("This court cannot rewrite the removal statute to grant itself subject matter jurisdiction."); Rutherford v. Merck \& Co., 428 F. Supp. 2d 842, 852 ("In the Court's view, [procedural misjoinder] is an improper expansion of the scope of federal diversity jurisdiction." (citing In re Norplant Contraceptive Prod. Liab. Litig., 976 F. Supp. 559, 561 (E.D. Tex. 1997))); see also Parsons supra note 26 , at 65 .

220. In re Prempro Prods. Liab. Litig., 591 F.3d 613, 620 (8th Cir. 2010).

221. See In re Propecia (Finasteride) Prod. Liab. Litig., No. 12-MD-2331 (JG)(VVP), No. $12-$ CV-2049 (JG)(VVP), 2013 WL 3729570, at *6-8 (E.D.N.Y. May 17, 2013) (concluding that the misjoinder was egregious because diversity was not apparent from the face of the complaint because of the plaintiffs' pleading tactics). 
result of products containing finasteride. ${ }^{222}$ The plaintiffs filed an action against Merck and Company and Merck Sharpe Dohme Corporation (Merck), manufacturers of drugs that contained finasteride. ${ }^{223}$ All of the plaintiffs alleged that they took finasteride products. Moreover, they clearly alleged which products Merck manufactured. However, the plaintiffs did not allege that the products they actually ingested were sold, distributed, or manufactured by Merck. As the court explained: "[t]his vague pleading tactic makes it impossible for the court to determine which of the plaintiffs are truly diverse from the defendants." 224

In addition, the court in Fosamax treated this "vague pleading tactic" as evidence that the plaintiffs structured their complaint in a manner to defeat removal. ${ }^{225}$ In that case, the court concluded that the "Plaintiffs [were] intentionally imprecise in naming Defendants, which [made] it impossible to determine whether some Plaintiffs truly are non-diverse from Defendants." 226 Thus, in finding that the misjoinder before it was egregious, the court noted that unlike Prempro, there was evidence that the complaint was strategically drafted to defeat removal.

Considering whether it is apparent from the face of the complaint if the plaintiffs are truly not diverse from the defendants allows the court to determine if the joinder rules are being manipulated to manufacture a non-diverse lawsuit. ${ }^{227}$ Framing it this way, the court can avoid exploring the plaintiffs' motive for the joinder. Instead, the court would be using an objective measure: the complaint. It may be true that one of the plaintiffs is from the same state as one of the defendants. However, this factor would require that specific plaintiff to assert a cause of action against that specific defendant. Viewing the complaint with this scrutiny would allow the court to determine if the joinder rules are being manipulated. Thus, courts should consider whether the diversity of citizenship is apparent from the face of the complaint.

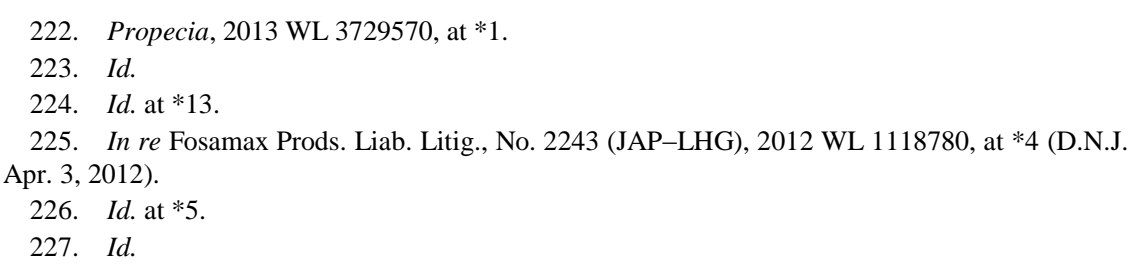




\section{Sufficient Factual Pleading to Support Joinder}

Finally, the court should consider whether the pleadings are sufficiently factually specific to support the joinder. ${ }^{228}$ In Fosamax, the plaintiffs alleged that the defendant's product caused them to suffer longbone fractures. However, the plaintiffs did "not identify with specificity which long bone(s) each individual injured. Rather Plaintiffs state[d] that they '[had] suffered and [could] continue to suffer severe and permanent personal injuries, including weakened or brittle bones, multiple stress fractures, and low energy femoral fractures." 229 The court concluded that the plaintiffs' allegations were "exceptionally vague, making it difficult for the Court to establish how the Plaintiffs share a connection, if any."230 The court seems to say that the plaintiffs' vague pleading made it impossible for the court to analyze whether the parties were properly joined under Rule 20.

Uncertainties that result from improper pleading should be resolved against the party who failed to plead properly. At the pleading stage of the litigation no one, other than the plaintiffs, can know what connection the plaintiffs share. The plaintiffs, then, should plead sufficient information that would support the joinder of the parties. Uncertainties that result from the plaintiffs' lack of proper pleading should not be resolved against the defendant. Those uncertainties should be resolved against the plaintiff, who failed to plead with sufficient detail. Thus, plaintiffs should have to provide a basis for the joinder by pleading with enough detail for the court to make a proper determination.

Considering whether the pleadings are sufficiently specific to support the joinder would help the court understand whether the parties are truly unrelated, or if there is a reasonable basis for the joinder of the parties. Therefore, the court should consider whether the pleadings are sufficiently specific to support the joinder because it would allow the court to determine if there is a reasonable basis for the joinder.

\section{CONCLUSION}

Since its adoption, the case law surrounding the procedural misjoinder doctrine has been neither consistent nor coherent. District

\footnotetext{
228. Id. at *5.

229. Id. at *1.

230. Id. at $* 5$.
} 
courts have struggled to apply the egregious standard as set out by the Eleventh Circuit in Tapscott, and nearly a decade and a half later, the Eighth Circuit's decision in Prempro. Neither court offered a clear standard of egregiousness to guide lower court application of procedural misjoinder. Thus, the doctrine remains muddled and litigants are left with uncertainty.

Although the development of the procedural misjoinder doctrine has been confusing, it should be adopted because it is necessary to allow courts to address the problem of joinder of unrelated parties. The Eighth Circuit missed the opportunity to clarify the confusing doctrine even though the time and circumstances for clarification were ideal. Other circuit courts considering the procedural misjoinder doctrine should avoid making the same mistake because the doctrine needs clarification. The current legal landscape therefore calls for clarification, not only because the standards applied to procedural misjoinder are often confusing and inconsistent, but also because the enactment of CAFA will likely make the problem of joinder of unrelated parties worse.

As a solution, therefore, courts addressing the procedural misjoinder doctrine should consider adopting a multi-factor test laid out in this comment, considering: 1) whether the misjoinder frustrates the purpose of permissive joinder; 2) whether the misjoinder meets the corresponding test for fraudulent joinder; 3) whether it is clear which plaintiffs have claims against which defendants; and 4) whether the pleadings are sufficiently specific to support the joinder. By considering these factors, courts would ensure that the doctrine is neither a confusing nor an inappropriate expansion of diversity jurisdiction. 